\author{
Jana ŠUGÁROVÁ ${ }^{1}$ \\ Martin FRNČÍK ${ }^{2}$ \\ Martin NECPAL ${ }^{3}$ \\ Jana MORAVČÍKOVÁ ${ }^{4}$ \\ Martin KUS $\mathbf{Y}^{5}$
}

\title{
EVALUATION OF TRIBOLOGICAL PROPERTIES OF LASER TEXTURED HARDENED TOOL STEELS
}

\begin{abstract}
In this paper the laser surface texturing (LST) technology as one of the methods of tribological properties modifying of mating steel surfaces is analysed. The area density of dimple-like depression along with the dimple diameter are the only main factors which significantly influence the friction coefficient value, therefore the effect of different values of area density of dimples: $6 \%, 11 \%$ and 16 $\%$ on the contact coefficient of friction was analysed. Surface textures were manufactured on the planar areas of compression platens ( $90 \mathrm{MnCrV} 8$ tool steel) using a pulsed-beam laser. The values of coefficients of friction were obtained via a ring compression test. Test sample compression was realized in lubrication-free and hydrodynamic regime. A significant improvement of tribological properties in contact steel areas was experimentally observed in both friction regimes. The results of experiments showed that by applying of surface texturing with defined shape and dimensions of dimples and lubricating oil at the same time, the coefficient of friction value can be reduced to about of $75 \%$.
\end{abstract}

Keywords: laser surface texturing (LST), tribological properties modification, coefficient of friction, ring compression test

\section{Introduction}

Laser surface texturing (LST) technology is a surface engineering process applied to improve surface tribological properties by production of regularly arranged microstructures on the contact surfaces of materials [1,2]. Various

\footnotetext{
1 Autor do korespondencji/corresponding author: Jana Šugárová, Slovak University of Technology, Faculty of Material Science and Technology, Bottova 25, 91724 Trnava, Slovakia,email: jana.sugarova@stuba.sk

2-5 Martin Frnčík, Martin Necpal, Jana Moravčíková, Martin Kusý, Slovak University of Technology, Faculty of Material Science and Technology, Bottova 25, 91724 Trnava, Slovakia, emails: martin.frncik@stuba.sk, martin.necpal@stuba.sk, jana.moravcikova@stuba.sk, martin.kusy@stuba.sk
} 
types of surface patterns have been analyzed, but the dimples and grooves are the most widely used for laser textured tribo-surfaces [3,4]. Surface texture can acts as lubricant reservoirs that can deliver the lubricant directly into the contact zone in starved oil lubrication [5,8]. Another critical function of the textured surfaces is trapping of wear particles, because the elimination of wear particles from the contact interface reduces friction and wear in both lubricated and dry sliding regime $[6,9]$. Furthermore, the textured surfaces can also increase load-carrying capacity $[6,7]$. Laser surface texturing technology has been used in many technological fields to improve the tribological performances of contact surfaces, such as mechanical seals [10,11], cutting tools [12-14], piston rings [15] and thrust bearing [16].

Dimple diameter, depth, and area density of dimples are the three major parameters of evenly distributed dimple patterns [17-19]. By considering all the geometric parameters, texture shapes are optimized to achieve the optimum shapes which will provide the best tribological performance in terms of minimum friction and maximum load carrying capacity [3]. Many researchers have contributed to the investigation on the influences of the above parameters on friction and load-carrying capacity of sliding surfaces $[19,20]$.

The area density of micro-dimples is another important parameter. In the works of Saeidi et al. [9] the effect of five chosen dimple parameters (depth, diameter, length, area density of dimples and sliding direction) has been analyzed. Authors found that the dimple diameter and the area density of dimples are the main factors which significantly influence the average coefficient of friction. For the tribo-pairs of metals lubricated by oil, several studies under controlled laboratory conditions have been performed in order to analyze the effect of area density of dimples on the coefficient of friction. Several experimental works show that the area density of dimples in the range of $5-13 \%$ is preferable for friction reduction, and the area density of dimples of above 20 $\%$ usually causes increasing the friction coefficient value [17, 21-23].

Many papers have examined the effect of dimple size, shape, and depth on friction reduction. No clear conclusions can be specified because there are additional factors influencing friction beside what were reported above (dimple size, shape, area density of dimples). Factors such as roughness of the nontextured surface area, pitch between dimples, uniformity of dimples, edge smoothness, dimple arrangement (pattern of dimple inside the contact), and the lack of control of dimple depths may all influence the friction phenomenon [24].

\section{Experimental setup}

This paper deals with the effect of different values of area density of dimples on the coefficient of friction value, which was measured at the toolworkpiece interface via a ring compression test. Each studied surface textures 
consist of dimple-like depressions with a diameter of $100 \pm 5 \mu \mathrm{m}$ and a depth of $11 \mu \mathrm{m}$. Depressions are situated at the corners of the regular hexagon with a given side length in order to achieve the appropriate area density of dimples. One depression is placed into the centre of this pattern, as shown in figure 1. Three area densities of dimples have been experimentally studied:

- $6 \%$, depicted in figure $1 \mathrm{a}$, with the hexagon side length of $0.389 \mathrm{~mm}$,

- $11 \%$, depicted in figure $1 \mathrm{~b}$, with the hexagon side length of $0.287 \mathrm{~mm}$,

- $16 \%$, depicted in figure 1c, with the hexagon side length of $0.238 \mathrm{~mm}$. Compression platens were made of $90 \mathrm{MnCrV} 8$ (according to EN ISO 4957) tool steel using turning technology. Chemical composition of used tool steel is specified in table 1. During the hardening process, which was carried out in the oil medium at the temperature of $770^{\circ} \mathrm{C}$, the compression platens gained the required hardness of $58 \pm 1$ HRC. Subsequently, the frontal surfaces of each platen were grinded to obtain a desired surface roughness Ra of 0.8 $\mu \mathrm{m}$.
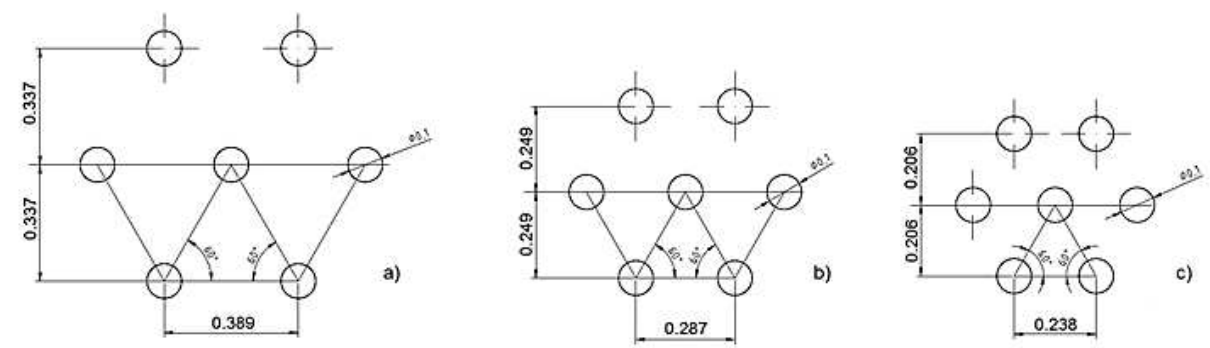

Fig. 1. Analysed surface textures with area density of dimples of $6 \%$ (a), $11 \%$ (b) and $16 \%$ (c)

Table 1. Chemical composition of 90MnCrV8 tool steel (wt. \%)

\begin{tabular}{|c|c|c|c|c|c|c|}
\hline $\mathrm{C}$ & $\mathrm{Si}$ & $\mathrm{Mn}$ & $\mathrm{P}_{\max }$ & $\mathrm{S}_{\max }$ & $\mathrm{Cr}$ & $\mathrm{V}$ \\
\hline 0.91 & $0.10-0.40$ & $1.90-2.10$ & 0.030 & 0.030 & $0.20-0.50$ & $0.05-0.15$ \\
\hline
\end{tabular}

Since there are strict dimensional and shape requirements for the texture dimples, it was necessary to experimentally define the optimal process parameters of laser beam, which will be subsequently used for production of various studied surface textures. For this purpose, a 3-level full factorial experiment has been carried out. Three laser texturing parameters as input factors were selected: laser beam repetition rate $f_{o}$, scanning speed $v_{s}$ and laser track displacement $\Delta$. The experimental factors and its levels are summarized in table 2 .

During this experiment, testing cavities of square shape with dimensions of $5 \times 5 \mathrm{~mm}$ were produced using specific combinations of input process parameters listed in table 2. Optimal process parameters $\left(f_{o}, v_{s}\right.$ and $\left.\Delta\right)$ are that ones, which contributes to the finest machined surface roughness $R_{a}$. In this 
factorial design, a 5-axis high precision laser machining centre LASERTEC 80 SHAPE has been used for testing cavities production. This machine is equipped with a pulsed fiber Nd:YAG laser with a wavelength of $1064 \mathrm{~nm}$. Laser beam power in each input parameter combination has been optimized in order to achieve the depth of cut of $1 \mu \mathrm{m}$ per one layer. Surface roughness measurement of each testing cavity was realized using a Carl Zeiss Surfcom 5000 machine in two perpendicular directions $\left(0^{\circ}\right.$ and $\left.90^{\circ}\right)$. Obtained surface roughness values from this experiment are listed in table 3.

Table 2. Factors and its levels

\begin{tabular}{|l|c|c|c|}
\hline \multirow{2}{*}{\multicolumn{1}{|c|}{ Factors }} & \multicolumn{3}{|c|}{ Factor levels } \\
\cline { 2 - 4 } & -1 & 0 & +1 \\
\hline Repetition rate $f(\mathrm{kHz})$ & 50 & 75 & 100 \\
\hline Scanning speed $v_{s}(\mathrm{~mm} \cdot \mathrm{s}-1)$ & 1000 & 1300 & 1600 \\
\hline Tracks displacement $\Delta(\mu \mathrm{m})$ & 5 & 10 & 15 \\
\hline Pulse duration time $t(\mathrm{~ns})$ & \multicolumn{3}{|c|}{120} \\
\hline
\end{tabular}

Table 3. Parameters of laser beam utilized to production of micro-dimples and surface roughness of cavities

\begin{tabular}{|c|c|c|c|c|c|c|c|c|}
\hline \multirow{2}{*}{ No. } & \multicolumn{2}{|c|}{$P$} & \multirow{2}{*}{$f_{o}(\mathrm{kHz})$} & \multirow{2}{*}{$v_{s}(\mathrm{~mm} / \mathrm{s})$} & \multirow{2}{*}{$\begin{array}{c}\Delta \\
(\mu \mathrm{m})\end{array}$} & \multirow{2}{*}{$\operatorname{Ra}_{0}{ }^{\circ}(\mu \mathrm{m})$} & \multirow{2}{*}{$\begin{array}{l}\mathrm{Ra} 90^{\circ} \\
(\mu \mathrm{m})\end{array}$} & \multirow{2}{*}{$\begin{array}{l}\mathrm{Ra}_{\mathrm{av}} \\
(\mu \mathrm{m})\end{array}$} \\
\hline & $(\%)$ & $(W)$ & & & & & & \\
\hline 1. & 15.30 & 7.96 & 50 & 1000 & 5 & 1.008 & 1.149 & 1.079 \\
\hline 2. & 19.50 & 10.14 & 50 & 1000 & 10 & 1.107 & 1.141 & 1.124 \\
\hline 3. & 23.0 & 11.96 & 50 & 1000 & 15 & 1.122 & 1.138 & 1.130 \\
\hline 4. & 17.50 & 9.10 & 50 & 1300 & 5 & 1.322 & 1.343 & 1.333 \\
\hline 5. & 21.0 & 10.92 & 50 & 1300 & 10 & 1.269 & 1.377 & 1.323 \\
\hline 6. & 25.50 & 13.26 & 50 & 1300 & 15 & 1.21 & 1.232 & 1.221 \\
\hline 7. & 18.0 & 9.36 & 50 & 1600 & 5 & 1.316 & 1.283 & 1.300 \\
\hline 8. & 23.0 & 11.96 & 50 & 1600 & 10 & 1.237 & 1.279 & 1.258 \\
\hline 9. & 27.80 & 14.46 & 50 & 1600 & 15 & 1.481 & 1.476 & 1.479 \\
\hline 10. & 17.30 & 13.84 & 75 & 1000 & 5 & 0.907 & 1.013 & 0.960 \\
\hline 11. & 23.50 & 18.80 & 75 & 1000 & 10 & 0.999 & 1.108 & 1.054 \\
\hline 12. & 27.20 & 21.76 & 75 & 1000 & 15 & 1.124 & 1.166 & 1.145 \\
\hline 13. & 20.50 & 16.40 & 75 & 1300 & 5 & 0.956 & 0.962 & 0.959 \\
\hline 14. & 26.50 & 21.20 & 75 & 1300 & 10 & 1.021 & 1.189 & 1.105 \\
\hline 15. & 30.80 & 24.64 & 75 & 1300 & 15 & 1.105 & 1.187 & 1.146 \\
\hline 16. & 21.80 & 17.44 & 75 & 1600 & 5 & 0.996 & 1.131 & 1.064 \\
\hline 17. & 28.0 & 22.40 & 75 & 1600 & 10 & 1.16 & 1.179 & 1.170 \\
\hline 18. & 33.50 & 26.80 & 75 & 1600 & 15 & 1.194 & 1.154 & 1.174 \\
\hline 19. & 17.0 & 17.0 & 100 & 1000 & 5 & 0.90 & 1.033 & 0.967 \\
\hline 20. & 23.50 & 23.50 & 100 & 1000 & 10 & 0.971 & 1.05 & 1.011 \\
\hline 21. & 27.50 & 27.50 & 100 & 1000 & 15 & 1.194 & 1.245 & 1.220 \\
\hline 22. & 20.0 & 20.0 & 100 & 1300 & 5 & 0.993 & 1.108 & 1.051 \\
\hline 23. & 26.0 & 26.0 & 100 & 1300 & 10 & 1.034 & 1.069 & 1.052 \\
\hline 24. & 30.0 & 30.0 & 100 & 1300 & 15 & 1.223 & 1.229 & 1.226 \\
\hline 25. & 22.0 & 22.0 & 100 & 1600 & 5 & 0.985 & 1.12 & 1.053 \\
\hline 26. & 28.50 & 28.50 & 100 & 1600 & 10 & 1.108 & 1.201 & 1.155 \\
\hline 27. & 33.80 & 33.80 & 100 & 1600 & 15 & 1.107 & 1.173 & 1.140 \\
\hline
\end{tabular}


Table 3 summarizes a design of the experiment including three input factors and three levels ( $3^{3}$ full factorial experiment, 27 runs). An optimised laser beam power $(P)$ for all runs is also stated in this table. Average machined surface roughness represents the desired response, which was measured in all combination of input parameters. It can be seen, that in run no. 13 the average machined surface roughness reached the lowest value from the all test runs. This is the reason why this combination of laser beam process parameters was chosen as the optimal for following production of surface textures on the planar surfaces of the compression platens.
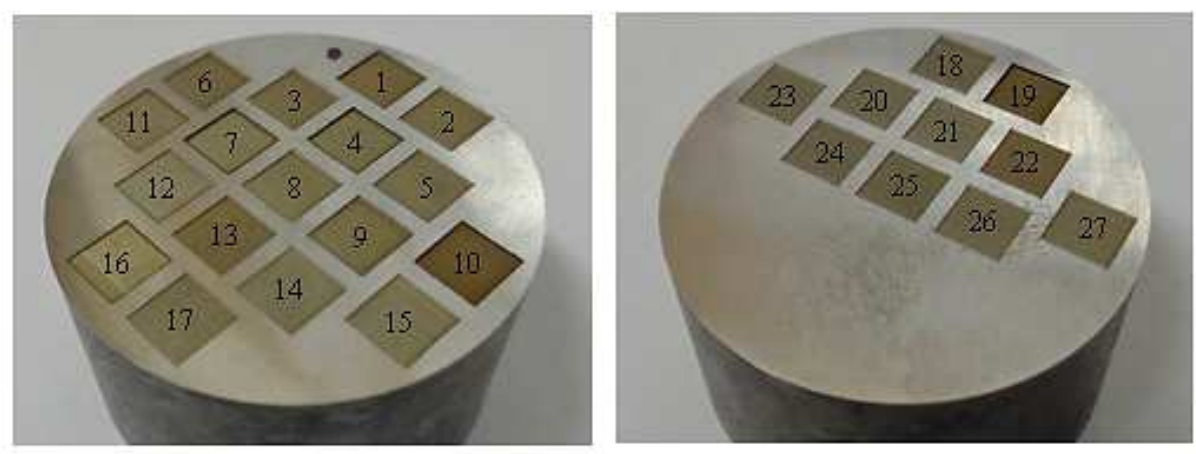

Fig. 2. Testing cavities manufactured in $3^{3}$ full factorial experiment

Figure 2 demonstrates the produced testing cavities. The surface colour variation is a result of various laser pulse energies. Figure 3 shows the real surface of the testing cavity produced under laser beam parameters: power $=$ $16.4 \mathrm{~W}$, repetition rate $=75 \mathrm{kHz}$, laser scanning speed $=1300 \mathrm{~mm} \cdot \mathrm{s}^{-1}$ and laser tracks distance $=5 \mu \mathrm{m}$ (run no. 13).

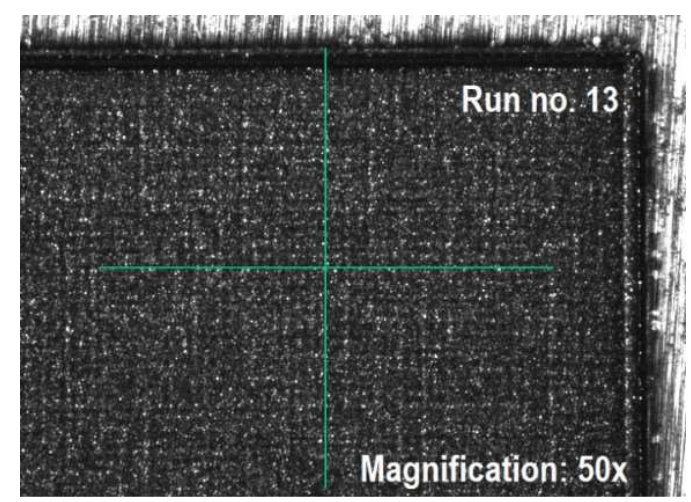

Fig. 3. Testing cavity with the finest machined surface roughness $(\mathrm{Ra}=0.959 \mu \mathrm{m})$ 
Surface textures production on the planar surfaces of compression platens has been carried out using the same laser machine, and optimal process parameters (run no. 13). Each surface texture was manufactured on the area of circle with a diameter of $16 \mathrm{~mm}$ (area of $201 \mathrm{~mm}^{2}$ ). Figure 4 shows the textures produced on the planar surfaces of the compression platens using a material ablation process. Production times for three different sample textures are listed in table 4.

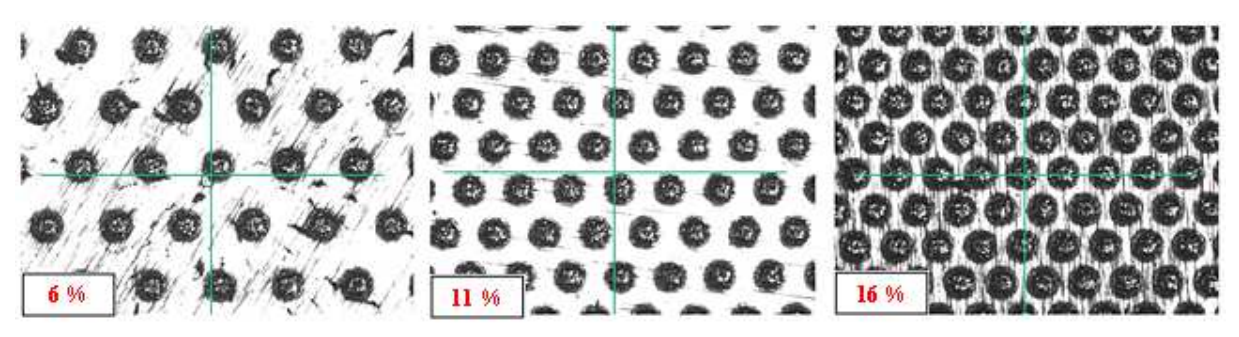

Fig. 4. Textures on the planar surfaces of compression platens produced using LST technology

Table 4. Production time of surface textures

\begin{tabular}{|c|c|c|}
\hline Area density of dimples & Number of depressions & Production time for one platen \\
\hline $6 \%$ & 1522 & $15 \min 41 \mathrm{~s}$ \\
\hline $11 \%$ & 2772 & $22 \min 45 \mathrm{~s}$ \\
\hline $16 \%$ & 4070 & $30 \min 47 \mathrm{~s}$ \\
\hline
\end{tabular}

Shape and dimensional characteristics of produced surface texture dimples have been carried out using laser confocal microscope Zeiss LSM 700 (with the resolution of $10 \mathrm{~nm}$ ). Overall shape and dimensions (diameter and depth) of chosen dimple of each studied texture were analyzed. Based on this analysis it can be concluded, that all chosen dimples meet the desired characteristics. Figure 5 represents the real 3D dimple shape of surface texture with area density of dimples of $6 \%$. Dimensional characteristics are: a dimple diameter of $98 \mu \mathrm{m}$ and a depth of $11 \mu \mathrm{m}$, dimple volume of about $39122 \mu \mathrm{m}^{3}$. This figure also shows that around the edge of depression a rim of solidified melt was created (average rim height is $6.1 \mu \mathrm{m}$ and a width of about $20 \mu \mathrm{m}$, rim volume is equal to $74553 \mu \mathrm{m}^{3}$ ). This rim is a typical element of the depressions manufactured by laser beam in material ablation processes. It has been experimentally demonstrated that these solidified melted rims around the edges of depressions have a negative effect on the tribological performance of contacting surfaces [21]. Therefore, to remove the rims formed in material ablation process all textured surfaces of all compression platens were polished with the polycrystalline diamond suspension (grain size of $1 \mu \mathrm{m}$, polishing time of $35 \mathrm{~s}$ ) using a Jeanwirtz TF250 polishing machine. The platens were subsequently cleaned in an ultrasonic bath in acetone medium in order to any 
polishing suspension or polishing debris were removed from the depressions (bath time of $30 \mathrm{~s}$ ).

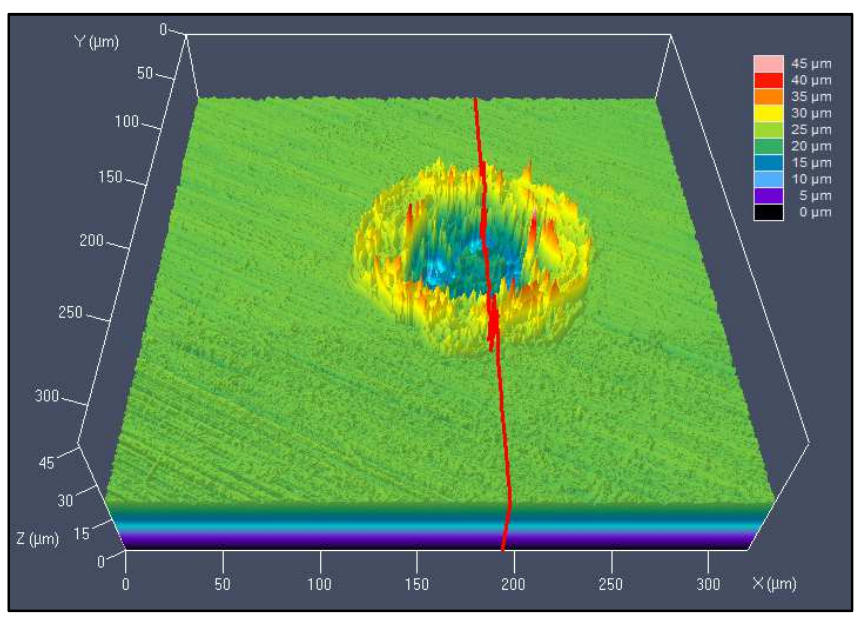

Fig. 5. Real 3D shape of selected depression of texture with area density of dimples of $6 \%$

A ring compression test was performed in order to determine the coefficient of friction values of the contact pairs. During this test, a ring-shaped test sample is axially compressed between the pair of textured compression platens. Test samples were manufactured of low carbon steel by turning technology. Frontal surfaces of test samples were non-textured. These surfaces have been grinded to obtain a required surface roughness ( $\mathrm{Ra}$ ) of $0.4 \mu \mathrm{m}$. Table 5 shows the chemical composition of test samples material. The ring compression test is based on the assumption that the coefficient of friction is constant at the whole contact surface and the deformation of the test ring is homogeneous. During the compression, the hole diameter of the test sample can be reduced, remain constant or even increased (depending on the value of the coefficient of friction). When the test sample is compressed in frictionless conditions, the hole diameter increases proportionally with the increase of the outer diameter. With the friction coefficient increasing the increase of the hole diameter is hampered and at a certain value of radial pressure this diameter can be reduced [25]. The ratio of outer diameter to the hole diameter to the height of test sample $\mathrm{D}: d: h$ is equal to $6: 3: 2$. The dimensions of test samples are typically $12 \mathrm{~mm}: 6 \mathrm{~mm}: 4 \mathrm{~mm}$ according to this ratio. It is important to preserve approximately an equal compression of the test sample $\Delta H$ during the test. This value should be within the range of 0.2 to $0.5 \mathrm{~mm}$. Ring compression test has been performed using an universal forming machine EU40; the strain rate was set up to the $10^{-4} \mathrm{~s}^{-1}$ value. 
Table 5. Chemical composition of test samples material (wt. \%)

\begin{tabular}{|c|c|c|c|}
\hline $\mathrm{C}_{\max }$ & $\mathrm{P}_{\max }$ & $\mathrm{S}_{\max }$ & $\mathrm{N}_{\max }$ \\
\hline 0.17 & 0.045 & 0.045 & 0.007 \\
\hline
\end{tabular}

Table 6. Selected physical and chemical properties of applied Renep CGLP 220 high performance slideway oil [26]

\begin{tabular}{|l|l|}
\hline Property & Value \\
\hline Viscosity at $40{ }^{\circ} \mathrm{C}\left(\mathrm{mm}^{2} / \mathrm{s}\right)$ & 220 (DIN EN ISO 3104) \\
\hline Density at $15^{\circ} \mathrm{C}\left(\mathrm{kg} / \mathrm{m}^{3}\right)$ & 895 (DIN 51 757) \\
\hline Flash point $\left({ }^{\circ} \mathrm{C}\right)$ & $240 \quad($ ISO 2592) \\
\hline Friction coefficient $(-)$ & 0.145 \\
\hline
\end{tabular}

Based on the deformation of the sample hole and the sample strain, coefficient of friction values can be simply defined for each compression. Coefficient of friction evaluation was performed in lubrication-free (dry contact) and hydrodynamic regimes at the room temperature of $21^{\circ} \mathrm{C}$. Both nontextured and textured compression platens were tested in these lubrication regimes for comparison. Three test samples were gradually compressed in each combination of surface texture and friction regime, subsequently the average value of coefficient of friction was calculated for each compression situation. To ensure the hydrodynamic regime ("full lubrication" configuration) the oilbased liquid lubricant Renep CGLP 220 was used. Physical and chemical properties of applied lubricant are depicted in table 6 .

\section{Results and discussion}

The average values of coefficient of friction evaluated based on the ring compression are summarized in table 7. Graphical comparison of these values is depicted in figure 6. According to the ring compression test, the reference value of the friction coefficient for non-textured compression platens (in lubrication-free regime) achieves the value of 0.258 . The coefficient of friction value for steel - steel contact pair should be within the range of 0.25 to 0.8 [27]. It was experimentally confirmed, that the coefficient of friction value for nontextured steel surfaces tested with the oil lubricant is 0.157 . This value is slightly higher than the value specified by the oil producer. This means that by using only the oil lubricant for modification of the tribological conditions of the mating surfaces, the coefficient of friction value can be reduced by $39.14 \%$. 
Table 7. Values of friction coefficient obtained via ring compression test

\begin{tabular}{|l|c|c|}
\hline \multirow{2}{*}{ Compression platen surface } & \multicolumn{2}{|c|}{ Friction coefficient (-) } \\
\cline { 2 - 3 } & $\begin{array}{c}\text { lubrication-free } \\
\text { regime }\end{array}$ & $\begin{array}{c}\text { hydrodynamic } \\
\text { regime }\end{array}$ \\
\hline Non-textured & $0.258 \pm 0.013$ & $0.157 \pm 0.0080$ \\
\hline Textured (6\%) & $0.137 \pm 0,007$ & $0.069 \pm 0.0010$ \\
\hline Textured $(11 \%)$ & $0.198 \pm 0.016$ & $0.116 \pm 0.0035$ \\
\hline Textured $(16 \%)$ & $0.254 \pm 0.005$ & $0.128 \pm 0.0065$ \\
\hline
\end{tabular}

A blue line in the figure 6 represents the coefficient of friction value evaluated using only the surface texturing for modification of tribological properties. The lowest value of the coefficient of friction was achieved using the surface texture with the area density of dimples of $6 \%$. The coefficient of friction reaches the value of 0.137 , which means that its value was reduced nearly to the half of its original value ( $46.90 \%$ reduction). The reason for this fact is that the contact area between the compression tools and test sample was sufficiently reduced which resulted in lower forming pressures and forces. Higher values of area density of dimples contribute to an increase in value of the coefficient of friction. This relation has strong linear character. Surface texture with area density of dimples of $16 \%$ reaches the coefficient of friction value of 0.254 , which is almost the same value as the reference ( $1.55 \%$ friction reduction). In this case, the surface texture does not contribute to friction reduction, because the space between the each dimple start acting like a peak of material, which makes the flow of test sample material more difficult during the deformation process. The friction coefficient value in lubrication-free regime can be evaluated from the following equation:

$$
f=0.0117 S_{p}+0.0676
$$

where, $f$ is the coefficient of friction (-) and $S_{p}$ is the area density of dimples $(\%)$. The value of a coefficient of determination is 0.99 . So, $99 \%$ of the variability in the response can be explained by the linear regression model.

A yellow line in the figure 6 represents the coefficient of friction value evaluated for the surface textures with the various densities and with the application of oil lubricant. The coefficient of friction value increases from the value of 0.069 to 0.128 with the increasing the value of the area density of dimples and similarly to the previous case, the relationship is linear. Combination of area density of $6 \%$ together with the oil lubricant contribute to the lowest value of coefficient of friction (0.069). In this case, compared to the nontextured surfaces with no lubricant and the non-textured surfaces with oil lubricant it was found that the reduction in the coefficient of friction value is equal to 73.26 and $56.05 \%$, respectively. There are two reasons why the coefficient of friction reaches a low value in these cases: (a) surface texture re- 
duced the contact area between the test sample and compression platens and, (b) micro-dimples act as a micro-reservoir for liquid lubricant.

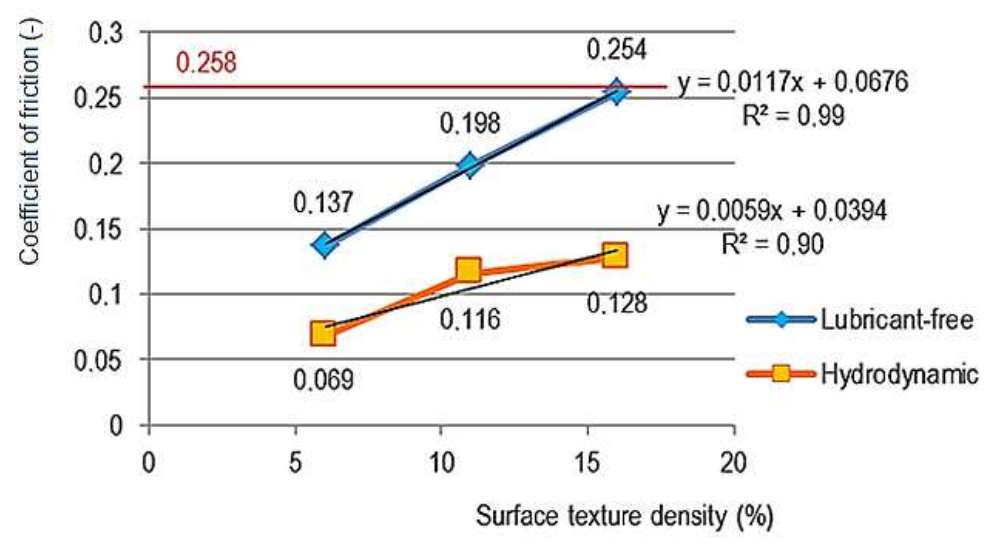

Fig. 6. Coefficient of friction value vs. the surface texture density

According to the [28] the most important surface texture parameter is the ratio of the dimple height to the dimple diameter. According to the Ronen et al. [29] this ratio value should be within the range of 0.1 to 0.2 in order to ensure the friction reduction in hydrodynamic lubrication regime. In this paper, the value of this ratio is 0.112 . Therefore, the coefficient of friction value reduction is so significant. The coefficient of friction value in hydrodynamic lubrication regime can be evaluated from the following equation:

$$
f=0.0059 S_{p}+0.0394
$$

where, the $f$ is the coefficient of friction (-) and $S_{p}$ is the area density of dimples (\%). The value of a coefficient of determination is 0.90 . So, $90 \%$ of the variability in the response can be explained by the linear regression model.

\section{Conclusion}

Laser surface texturing technology is a widely used method to improve the load capacity, the wear resistance, and the friction coefficient of tribological components. To analyse the influence of laser texturing on the coefficient of friction measured at the tool - workpiece interface a dimple-like depressions with a depth of $11 \mu \mathrm{m}$, a diameter of $98 \mu \mathrm{m}$ and a texture densities of $6 \%, 11 \%$ and $16 \%$ has been formed in the planar areas of compression platens made of $90 \mathrm{MnCrV} 8$ steel. Laser texturing has been carried out using a pulsed fiber Nd:YAG laser with power of $16.4 \mathrm{~W}$, repetition rate of $75 \mathrm{KHz}$ and laser track displacement of $5 \mu \mathrm{m}$. The morphological characterization of manufactured dimples has been performed using a laser confocal microscope. Tribo- 
logical tests have been carried out in two different lubrication regimes, i.e. lubricant-free and hydrodynamic, where oil lubricant with viscosity of $220 \mathrm{~mm}^{2} \cdot \mathrm{s}^{-}$

${ }^{1}$ was used at room temperature.

Experimental results showed a significant improvement of friction behaviour under hydrodynamic conditions. Textured contact surface with the area density of dimples of $6 \%$ modified by oil lubricant showed the best friction behaviour compared to the reference value. Reference value of the coefficient of friction, corresponding to a non-textured surface, was established at a value of 0.258 . In this case, the coefficient of friction value was reduced to a value of 0.069 (73.26\% reduction in value), which means, that surface texturing with defined and suitable shape and dimensions of dimples, and using an appropriate liquid lubricant at the same time, the value of coefficient of friction can be reduced to about of $75 \%$. A similar improvement of friction behaviour using a surface texture was observed in lubrication-free regime too. Surface texture with dimple density of $6 \%$ contributed to friction reduction to about of $46.9 \%$. Increasing of coefficient of friction with the increase of dimple density was observed in both friction regimes; these functionalities have strong linear character.

The surface texturing is an important process in reducing friction and wear. The reduction of contact area, the function of micro-trap for wear debris, and the micro-reservoirs for lubricant retention are the main mechanisms responsible for reducing the friction and wear in laser surface texturing.

\section{Acknowledgement}

This research work was supported by an international research project under the MANUNET 2014 call, entitled: Innovative methods of sheet metal forming tools surfaces improvement - R\&D (2014/11283); VEGA project called: Laser surface texturing technology research for an optimizing of tribological conditions in the sheet metal forming processes $(1 / 0669 / 15)$. The authors would also like to thank for financial contribution from the SUT Grant scheme for Support of Young Researchers (1350/16).

\section{References}

[1] Wang Z. et al.: Angle-dependent lubricated tribological properties of stainless steel by femtosecond laser surface texturing, Optics Laser Technol., 81 (2016) 6066.

[2] Etsion I.: State of the art in Laser surface texturing, J., Tribology, 127 (2005) 248253.

[3] Ibatan T. et. al.: Recent development on surface texturing in enhancing tribological performance of bearing sliders, Surface Coatings Technol., 272 (2015) 102120.

[4] Yan J. et. al.: Fabricating micro-structured surface by using single-crystalline diamond endmill, Int. J. And. Manuf. Technol., 51 (2010) 957-964. 
[5] Vilhena L. M. et. al.: Surface texturing by pulsed Nd:YAG laser, Tribology Int., 42 (2009) 1496-1504.

[6] Gualtieri E. et. al.: Increasing nanohardness and reducing friction of nitride steel by laser surface texturing, Tribology Int., 42 (2009) 699-705.

[7] Shinkarenko A. et al.: The effect of surface texturing in soft elasto-hydrodynamic lubrication, Tribology Int., 42 (2009) 284-292.

[8] Fowell M. et al.: Entrainment and inlet suction: Two mechanisms of hydrodynamic lubrication in textured bearings, J. Tribology, 129 (2007) 336-347.

[9] Saeidi F. et al.: Effect of surface texturing on cast iron reciprocating against steel under starved lubrication conditions: A parametric study, Wear, 348-349 (2016) 17-26.

[10] Wan Y. and Xiong D.-S.: The effect of laser surface texturing on frictional performance of face seal, J. Mat. Proc. Technol., 197 (2008) 96-100.

[11] Feldman Y. et al.: A hydrostatic laser surface textured gas seal, Tribology Letters, 22 (2006) 21-28.

[12] Walter C. et. al.: Laser-structured grinding tools- Generation of prototype patterns and performance evaluation, J. Mat. Proc. Technol., 214 (2014) 951-961.

[13] Dumitru G. et al.: Laser processing of hardmetals: Physical basics and applications. Int. J. Refractory Metals Hard Mat., 23 (2005) 278 - 286.

[14] Kümmel J. et al.: Study on micro texturing of uncoated cemented carbide cutting tools for wear improvement and built-up edge stabilization, Journal of Materials Processing Technology, 215 (2015) 62-70.

[15] Ryk G., Etsion I.: Testing piston rings with partial laser surface texturing for friction reduction, Wear, 261 (2006) 792-796.

[16] Brizmer V. et. al.: A laser surface textured parallel thrust bearing, Tribology transactions, 46 (2003) 397-403.

[17] Yan D. et. al.: Significance of dimple parameters on the friction of sliding surfaces investigated by orthogonal experiments, Tribology Trans., 53 (2010) 703-712.

[18] Ma Ch., Zhu H.: An optimum design model for textured surface with ellipticalshape dimples under hydrodynamic lubrication, Tribology Int., 44 (2011) 987995.

[19] Wang X. et. al.: Design principles for the area density of dimple patterns, J. Eng. Tribology, 229 (2015) 538-546.

[20] Galda L. et. al.: Dimples shape and distribution effect on characteristics of Stribeck curve, Tribology Int., 42 (2009) 1505-1512.

[21] Kovalchenko A. et. al.: The effect of laser surface texturing on transitions in lubrication regimes during unidirectional sliding contact, Tribology Int., 38 (2005) 219-225.

[22] Ryk G. et. al.: Experimental investigation of laser surface texturing for reciprocating automotive components, Tribology Trans., 45 (2002) 444-449.

[23] Grabon W. et. al.: Improving tribological behaviour of piston ring-cylinder liner frictional pair by liner surface texturing, Tribology Int., 61 (2013) 102-108.

[24] Hsu S. M. et. al., Friction reduction using discrete surface textures: principle and design, J. Physics D: Applied Physics, 47 (2014) 335307. 
[25] Plančak M. et. al.: Possibilities to measure contact friction in bulk metal forming, Tehnički vjesnik, 19 (2012) 727-734.

[26] Renep CGLP, 2013, Fuchs product information, online: <http://www3.ikaros. net/datablad/pblad/smorjmede1\%20(Univar)/600631321_Renep_CGLP_PBLAD.

[27] The Engineering ToolBox, 2014, Friction and coefficients of friction, online: $<$ http://www.engineeringtoolbox.com/friction-coefficients-d_778.

[28] Shinkarenko A. et. al.: Theoretical analysis of surface-textured elastomer sleeve in lubricated rotary sliding, Tribology Trans., 53 (2010) 376-385.

[29] Ronen A. et. al.: Friction-reducing surface-texturing in reciprocating automotive components, Tribology Trans., 44 (2001) 359-366.

\section{OCENA WŁAŚCIWOŚCI TRIBOLOGICZNYCH HARTOWANYCH STALI NARZĘDZIOWYCH TEKSTUROWANYCH LASEROWO}

\section{Streszczenie}

$\mathrm{W}$ artykule przedstawiono analizę technologii laserowego teksturowania powierzchni (LTP) jako jedną z metod modyfikacji właściwości tribologicznych współpracujących powierzchni stalowych. Podstawowy szyk tekstury powierzchni składa się z wgłębień o zakrzywionym dnie, które są umieszczone w narożach sześciokąta foremnego. Dodatkowo jedno zagłębienie jest umieszczone w środku szyku. Parametry zagłębień są następujące: średnica $100 \pm 5 \mu \mathrm{m}$, głębokość $11 \mu \mathrm{m}$, stosunek głębokości do średnicy 0,11 . Gęstość powierzchniowa wgłębień oraz średnica wgłębienia są głównymi czynnikami, które w sposób istotny wpływają na wyjściową wartość współczynnik tarcia, dlatego analizowano wpływ różnych wartości gęstości powierzchniowej wgłębień, tj. $6 \%, 11 \%$ i 16\% na wartość kontaktowego współczynnika tarcia. Tekstury powierzchni zostały utworzone na płaskich powierzchniach płyt dociskowych (stal narzędziowa $90 \mathrm{MnCrV} 8$ ) za pomocą wiązki pulsacyjnej lasera. Wartości współczynników tarcia otrzymano za pomocą testu ściskania pierścienia. Próbki do badań ze stali węglowej S235JRG1 były ściskane osiowo pomiędzy parą teksturowanych płyt dociskowych. Ściskanie badanej próbki zostało zrealizowane w warunkach braku smarowania oraz smarowania hydrodynamicznego. Wyniki doświadczalne wykazały, że przez zastosowanie teksturowania powierzchni o określonym kształcie i wymiarach wgłębień oraz ciekłego smaru, wartość współczynnika tarcia może być zmniejszona prawie o $75 \%$.

Słowa kluczowe: teksturowanie laserowe powierzchni (TLP), modyfikacja właściwości tribologicznych, współczynnik tarcia, test ściskania pierścienia

DOI: $10.7862 / \mathrm{rm} .2016 .19$

Otrzymano/received: $30.05 .2016 \mathrm{r}$.

Zaakceptowano/accepted: 12.09.2016 $r$. 